\title{
A new species and a new record of Laccaria (Fungi, Basidiomycota) found in a relict forest of the endangered Fagus grandifolia var. mexicana
}

\author{
Antero Ramos', Victor M. Bandala', Leticia Montoya' \\ I Red Biodiversidad y Sistemática, Instituto de Ecología, A.C., P.O. Box 63, Xalapa, Veracruz 91000, Mexico \\ Corresponding author: Leticia Montoya (leticia.montoya@inecol.mx)
}

Academic editor: T.Lumbsch | Received30 September 2017 | Accepted 15 November 2017 | Published27 November 2017

Citation: Ramos A, Bandala VM, Montoya L (2017) A new species and a new record of Laccaria (Fungi, Basidiomycota) found in a relict forest of the endangered Fagus grandifolia var. mexicana. MycoKeys 27: 77-94. https://doi.org/10.3897/ mycokeys.27.21326

\begin{abstract}
Two species of Laccaria discovered in relicts of Fagus grandifolia var. mexicana forests in eastern Mexico are described based on the macro- and micromorphological features, and their identity supported by molecular analysis of the internal transcribed spacer (ITS) and large subunit (LSU) of the ribosomal RNA gene. The phylogeny obtained here showed that one of the Mexican species is nested in an exclusive clade which in combination with its striking morphological features, infers that it represents a new species, while the other species is placed as a member in the Laccaria trichodermophora clade. This is the first report in Mexico of Laccaria with Fagus grandifolia var. mexicana trees, with which the reported species may form ectomycorrhizal association. Descriptions are accompanied with illustrations of macro- and micromorphological characters and a discussion of related taxa are presented.
\end{abstract}

\section{Keywords}

Ectomycorrhizal fungi, ITS, Neotropical fungi, nLSU, Tricholomatales

\section{Introduction}

It has long been recognized that Laccaria species are important ectomycorrhizal associates of ectotrophic plants worldwide (Mueller 1992). They are known to form interactions, for example with members of the Pinaceae, Dipterocarpaceae, Fagaceae, Betulaceae, Myrtaceae,

Copyright Antero Ramos et al. This is an open access article distributed under the terms of the Creative Commons Attribution License (CC BY 4.0), which permits unrestricted use, distribution, and reproduction in any medium, provided the original author and source are credited. 
Tiliaceae and Salicaceae (Kropp and Mueller 1999, Wilson et al. 2013). Some species as Laccaria laccata and L. bicolor have been considered host-generalists, and inclusive, have been subject of a lot of in vitro experimentation worldwide. However, recent studies developed based on molecular systematics showed that under those names, complexes of species are included (Taylor et al. 2006, Jargeat et al. 2010, Vincenot et al. 2012, Sheedy et al. 2013, Popa et al. 2014). A wide ectomycorrhizal host range has also been attributed to L. amethystina, but in this case it has some support for its generalist abilities at the population genetics level by Roy et al. (2008), while consideration for cryptic biological species was discarded, at least among the populations sampled in France.

In the monographic work of Laccaria by Mueller (1992), 19 species are recognized from North America, and 40 worldwide. New or potential undescribed species from different regions, based on morphological and molecular characteristics of fructifications, or on DNA identifications of environmental samples, have been discovered recently (Wang et al. 2004, Osmundson et al. 2005, Sheedy et al. 2013, Wilson et al. 2013, 2017, Montoya et al. 2015, Luo et al. 2016, Popa et al. 2014, 2016). Nowadays, MycoBank recognizes 112 records in this group of fungi, and additionally, Wilson et al. (2017) inferred 116 phylogenetic species from 30 countries covering the known geographic range of Laccaria. During the advances on the systematics of the group, a small number of morphological (macro- and microscopic) features had been found taxonomically informative (McNabb 1972, Mueller 1992), which may be the cause of false interpretations, leading to conceptual misunderstandings. In fact, since early taxonomic studies on the group, the need to revise the species of Laccaria commonly treated under names widely cited in the literature was considered as an important task, due to the existence of different, even undescribed species, confused under apparently wellknown ones, such as in the groups of L. laccata (Scop.) Cooke and L. proxima (Boud.) Pat. (Singer 1967, Mueller and Sundberg 1981, Irving et al. 1985). For example, the study by Sheedy et al. (2013) based on DNA multigene sequences, even noted that cryptic phylogenetic species were not nested as sister taxa. Thus, strict species identifications and achieving phylogenetic inferences with stronger resolution in Laccaria, will aid in building a robust data set, dealing with each species ectomycorrhizal host range.

In Mexico, the reports of the diversity of the genus Laccaria include about 17 species (Aguirre-Acosta and Pérez-Silva 1978, Bandala et al. 1988, Montoya et al. 1987, 2015, Cifuentes et al. 1990, Pérez-Silva et al. 2006, Garibay-Orijel et al. 2009). The edibility and use of some species as food has been documented (e.g. Montoya et al. 1987, Montoya-Esquivel et al. 2002, 2003, Lampman 2007, Pérez-Moreno et al. 2008) and ectomycorrhizae formed under in vitro culture conditions, isolated from native specimens have also been achieved (Santiago-Martínez et al. 2003, CarrascoHernández et al. 2010, Galindo-Flores et al. 2015). Molecular studies on most of those records are needed not only to support their identifications but for being included in phylogenetic studies. Laccaria roseoalbescens T. J. Baroni, Montoya and Bandala, described as new (Montoya et al. 2015) from the mesophytic forest in Veracruz, was recognized under morphological features and confirmed through phylogenetic DNA sequence analyses and recently incorporated by Luo et al. (2016) in their mo- 
lecular phylogeny to confirm the distinction of the new L. rubroalba X. Luo, L. Ye, Mortimer \& K.D. Hyde from China.

We have under research the fungal community associated to the two southernmost relicts of mesophytic forests dominated by Fagus grandifolia var. mexicana in the American Continent. This tree species is currently in danger of extinction and in the Red list of Mexican cloud forest trees, inhabiting a narrow range of nearly $145 \mathrm{hm}^{2}$ in Mexico (Rodríguez-Ramírez et al. 2013, Montoya et al. 2017). Taking into account its current status, we consider important to document the associated fungal species with particular focus to the ectomycorrhizal forming species. During our study, we found two species of Laccaria which after their morpho- and molecular analyses we concluded that with strong support can be recognized, one as L. trichodermophora G.M. Mueller and the other, as a distinct undescribed species close to L. angustilamella Zhu L., Yang \& L. Wang from China. As both are part of the unknown potential mycobionts of this endangered ectotrophic tree species, we were motivated to document them.

\section{Materials and methods}

\section{Sampling and morphological study of basidiomes}

Random visits were conducted during August-September 2005 and 2007, in two stands of Fagus grandifolia var. mexicana from Veracruz, Mexico, one in Acatlán Volcano, Acatlán $\left(19^{\circ} 40^{\prime} 43.9^{\prime \prime} \mathrm{N} ; 96^{\circ} 51^{\prime} 9.8^{\prime \prime} \mathrm{W}, 1840 \mathrm{~m}\right)$ and the other in Mesa de la Yerba, Acajete $\left(19^{\circ} 33^{\prime} 37.2^{\prime \prime N}\right.$; 9701'9.8"W, 1900 m). Basidiomes of Laccaria growing close to Fagus were gathered. Macromorphological characters and color were recorded, alphanumeric color codes in descriptions refer to Kornerup and Wanscher (1967). Measurements and colors of micromorphological structures were recorded in $3 \% \mathrm{KOH}$. Basidiospores were studied in Melzer's reagent. Methods to determine spore ranges are those used by Montoya and Bandala (2003), with 45-50 spores measured per collection (length and width of the sporoid excluding the ornamentation) and given as a range with the symbol $\bar{X}$ representing mean values. $\bar{Q}$ represents the basidiospore length/width ratio and is given as range of mean values. Line drawings were made with a drawing tube. The examined specimens studied are deposited in XAL herbarium (acronym from B. Thiers, continuously updated; Index Herbariorum: http://sweetgum.nybg.org/ih/). The SEM images were obtained after critical point drying of pieces of lamellae previously rehydrated in ammonia, fixed in glutaraldehyde and dehydrated in an ethanol series (Bandala and Montoya 2000).

\section{DNA extraction, PCR amplification, and sequencing}

Genomic DNA of the Mexican specimen was extracted according to Montoya et al. (2014). PCR was performed to amplify the ITS (Internal Transcribed Spacer) and LSU (Large Subunit) regions of the nuclear rDNA, using primers ITS1F, ITS5/ITS4, 
LR0R/LR21, LR7 (Vilgalys and Hester 1990, White et al. 1990, Gardes and Bruns 1993). PCR conditions, as well as procedures for the purification of amplified PCR products, cycle sequencing reactions and their purification were done according to Montoya et al. (2014). Once sequences were assembled and edited, they were deposited at GenBank database (Benson et al. 2017) (Table 1).

\section{Phylogenetic methods}

The phylogenetic analysis was performed with the sequences obtained in this study, as well as some retrieved from GenBank (http://www.ncbi.nlm.nih.gov/) derived from the Blast analysis (only those that best match), and complemented with related sequences used by Osmundson et al. (2005), Montoya et al. (2015) and Wilson et al. (2017) (Table 1). For this purpose, we constructed a dataset (ITS+LSU) using PhyDE v.0.9971 (Müller et al. 2010), also with MEGA 6.06 (Tamura et al. 2013) calculated the best evolutionary model and constructed the phylogenetic tree under the method of Maximum Likelihood (ML) with 500 bootstrap replications, and finally with MrBayes v 3.2.6 (Ronquist et al. 2012) constructed the phylogenetic tree (as Montoya et al. 2014) under the method of Bayesian Inference (BI). The phylogenies from ML and BI analyses were displayed using Mega 6.06 and FigTree v1.4.3 (Rambaut 2016) respectively.

\section{Results}

A total of 13 new ITS and 28S sequences for Laccaria were generated in this study (Table 1 and alignment in TreeBASE S21413). They were obtained from Laccaria samples proceeding from the two stands of Fagus grandifolia var. mexicana in the subtropical cloud forest in central Veracruz (sample AR24 comes from a conifers forest in Veracruz) (Table 1). Only bootstrap values of $\geq 70 \%$ and posterior probabilities (ML/ PP) of $\geq 0.90$ were considered and indicated on the tree branches. The phylogeny displayed (Fig. 1) inferred the Mexican samples clustered in two distinct clades. A group clearly related to Laccaria trichodermophora and another, in a separate clade, representing an undescribed species.

\section{Taxonomy}

Laccaria squarrosa Bandala, Montoya \& Ramos, sp. nov. MycoBank: MB823034

Figs 2-5

Holotype. MEXICO, Veracruz State, Mpio. Acatlán, Volcán de Acatlán, Aug 142007 , DM 63 (XAL). Terrestrial under Fagus grandifolia var. mexicana. 
Table I. Laccaria taxa included in this study: samples, location and GenBank accession number for sequences.

\begin{tabular}{|c|c|c|c|c|}
\hline \multirow{2}{*}{ Taxon } & \multirow{2}{*}{ Voucher } & \multirow{2}{*}{ Location } & \multicolumn{2}{|c|}{ GenBank } \\
\hline & & & ITS & $28 S$ \\
\hline Cortinarius violaceus & MTS 4854 (WTU) & USA: Washington & DQ486695 & DQ457662 \\
\hline L. alba & AWW438 & China: Yunnan-Shangrila & JX504094 & JX504178 \\
\hline L. alba & F1120750 & China & JX504126 & JX504206 \\
\hline L. alba & F1121461 & China & JX504129 & JX504209 \\
\hline L. alba & GMM6131 & China: Chang Bai Shan & JX504131 & JX504210 \\
\hline L. amethystea & FP-98556 & Germany: Vorpommern & DQ499640 & - \\
\hline L. amethystea & TUB 011464 & Germany & AF539737 & - \\
\hline L. amethysteo-occidentalis & AWW556 & USA: California, Nevada Co. & JX504107 & JX504191 \\
\hline L. amethysteo-occidentalis & AWW590 & USA: Oregon, Benton Co. & JX504112 & JX504195 \\
\hline L. amethystina & ALB183 & China: Tibet & JX504092 & JX504176 \\
\hline L. amethystina & F1123822 & USA: Wisconsin & KU685760 & KU685911 \\
\hline L. amethystina & GMM7041 & Russia: Caucasus & KU685654 & KU685797 \\
\hline L. amethystina & GMM7621 & $\begin{array}{c}\text { France: Forest comaniale de } \\
\text { Ste. Croix }\end{array}$ & JX504150 & JX504224 \\
\hline L. amethystina & LaAM-08-1 & - & JGI Genome & JGI Genome \\
\hline L. angustilamella & BAP226 & China: Yunnan & JX504118 & JX504201 \\
\hline L. angustilamella & HKAS58714 & China: Yunnan, Yongping & JX504168 & JX504244 \\
\hline L. aurantia & KUN-F 78557-Type & China: Yunnan & JQ670895 & - \\
\hline L. aurantia & MB-FB-101109 & China: Yunnan & JQ681209 & - \\
\hline L. bicolor & AWW539 & USA: Illinois & KM067817 & KU685763 \\
\hline L. bicolor & AWW537 & USA: Illinois, Johnson Co. & JX504105 & JX504189 \\
\hline L. major & GMM6012 & Costa Rica & KU685758 & KU685909 \\
\hline L. major & GMM6019 & Costa Rica & KU685757 & KU685908 \\
\hline L. nobilis & F1091206 & USA: Michigan & KU685636 & KU685779 \\
\hline L. ochropurpurea & JMP0038 & USA: Wisconsin & EU819479 & - \\
\hline L. ochropurpurea & KH_LA06_016 & USA: Louisiana & KU685721 & - \\
\hline L. ochropurpurea & PRL3777 & USA: Illinois & KU685732 & JX504246 \\
\hline L. ochropurpurea & PRL4777 & USA: Illinois & KU685733 & KU685883 \\
\hline L. proxima & F1133825 & USA: Mississippi & KU685642 & KU685786 \\
\hline L. roseoalbescens & LM5042 & Mexico: Veracruz & KJ874327 & KJ874330 \\
\hline L. roseoalbescens & LM5099-Type & Mexico: Veracruz & KJ874328 & KJ874331 \\
\hline L. salmonicolor & GMM7596-Type & China: Tibet & JX504143 & JX504218 \\
\hline L. salmonicolor & GMM7602 & China: Tibet & JX504145 & JX504220 \\
\hline L. sp. & A0561 & Japan: Sapporo & JX504082 & - \\
\hline L. sp. & A0573 & Japan: Narusawa & KU685617 & - \\
\hline L. sp. & GMM6800 & Guatemala & KU685756 & KU685907 \\
\hline L. squarrosa $a^{a}$ & DM121 & Mexico: Veracruz & MF669960 & MF669967 \\
\hline L. squarrosa $a^{a}$ & DM63-Type & Mexico: Veracruz & MF669958 & MF669965 \\
\hline L. squarrosa ${ }^{a}$ & DM93 & Mexico: Veracruz & MF669959 & MF669966 \\
\hline L. trichodermophora & TENN42523-Type & USA: Texas & DQ149868 & - \\
\hline L. trichodermophora & F1111951 & Costa Rica & KU685640 & KU685784 \\
\hline L. trichodermophora & GMM7733 & USA: Texas, Tyler Co. & JX504157 & JX504230 \\
\hline L. trichodermophora & KH_LA06_013 & USA: Louisiana & KM067881 & KU685872 \\
\hline
\end{tabular}




\begin{tabular}{|c|c|c|c|c|}
\hline \multirow{2}{*}{ Taxon } & \multirow{2}{*}{ Voucher } & \multirow{2}{*}{ Location } & \multicolumn{2}{|c|}{ GenBank } \\
\hline & & & ITS & $28 S$ \\
\hline L. trichodermophora & GMM7735 & USA: Texas & KM067872 & - \\
\hline L. trichodermophora & KH-LA06-012 & USA: Louisiana & KM067880 & - \\
\hline L. trichodermophora & GMM7734 & USA: Texas & KM067871 & - \\
\hline L. trichodermophora & KH-LA06-007 & USA: Louisiana & KM067874 & - \\
\hline L. trichodermophora & KH-LA06-008 & USA: Louisiana & KM067875 & - \\
\hline L. trichodermophora & tri1125225 & USA: Rocky Mountains & DQ149855 & - \\
\hline L. trichodermophora & KH-LA06-010 & USA: Louisiana & KM067878 & - \\
\hline L. trichodermophora & KH-LA06-011 & USA: Louisiana & KM067879 & - \\
\hline L. trichodermophora & KH-LA06-009 & USA: Louisiana & KM067876 & - \\
\hline L. trichodermophora & KH-LA06-009B & USA: Louisiana & KM067877 & - \\
\hline L. trichodermophora & KH-LA06-004 & USA: Louisiana & KM067873 & - \\
\hline L. trichodermophora & HC-PNNT-112 & Mexico: Mexico State & KT875031 & - \\
\hline L. trichodermophora & GO-2009-266 & Mexico: Mexico State & KC152147 & - \\
\hline L. trichodermophora & HC-PNNT-157 & Mexico: Mexico State & KT875032 & - \\
\hline L. trichodermophora & GO-2009-305 & Mexico: Distrito Federal & KC152149 & - \\
\hline L. trichodermophora & GO-2010-124 & Mexico: Veracruz & KC152144 & - \\
\hline L. trichodermophora & EF36 & Mexico & KT354980 & - \\
\hline L. trichodermophora & CB08167 & Mexico: Mexico State & KT875029 & - \\
\hline L. trichodermophora & GO-2009-228 & Mexico: Mexico State & KC152146 & - \\
\hline L. trichodermophora & GO-2010-126 & Mexico: Veracruz & KC152145 & - \\
\hline L. trichodermophora & GO-2010-082 & Mexico: Tlaxcala & KC152152 & - \\
\hline L. trichodermophora & GO-2009-225 & Mexico: Mexico State & KC152143 & - \\
\hline L. trichodermophora & GO-2009-484 & Mexico: Tlaxcala & KC152151 & - \\
\hline L. trichodermophora & HC-PNNT-192 & Mexico: Mexico State & KT875033 & - \\
\hline L. trichodermophora & GO-2009-210 & Mexico: Mexico State & KC152148 & - \\
\hline L. trichodermophora & HC-PNNT-132 & Mexico: Mexico State & KT875030 & - \\
\hline L. trichodermophora & GO-2009-314 & Mexico: Jalisco & KC152150 & - \\
\hline L. trichodermophora & HC-PNNT-099 & Mexico: Mexico State & KT875034 & - \\
\hline L. trichodermophora & GMM7714 & USA: Texas & KM067867 & - \\
\hline L. trichodermophora & GMM7712 & USA: Texas & KM067866 & - \\
\hline L. trichodermophora & GMM7716 & USA: Texas & KM067869 & - \\
\hline L. trichodermophora & HMJAU26938 & - & KP128033 & - \\
\hline L. trichodermophora & GMM7703 & USA: Texas & KM067865 & - \\
\hline L. trichodermophora & GMM7697 & USA: Texas & KM067863 & - \\
\hline L. trichodermophora & GMM7698 & USA: Texas & KM067864 & - \\
\hline L. trichodermophora ${ }^{a}$ & Montoya 4393 & Mexico: Veracruz & MF669961 & MF669968 \\
\hline L. trichodermophora ${ }^{a}$ & Montoya 4394 & Mexico: Veracruz & MF669962 & MF669969 \\
\hline L. trichodermophora ${ }^{a}$ & AR24 & Mexico: Veracruz & MF669964 & MF669970 \\
\hline L. trichodermophora ${ }^{a}$ & Bandala 4282 & Mexico: Veracruz & MF669963 & - \\
\hline Psathyrella rhodospora & MP133 MN & - & DQ267129 & AY645058 \\
\hline
\end{tabular}

${ }^{\mathrm{a}}$ samples and sequences obtained here. 


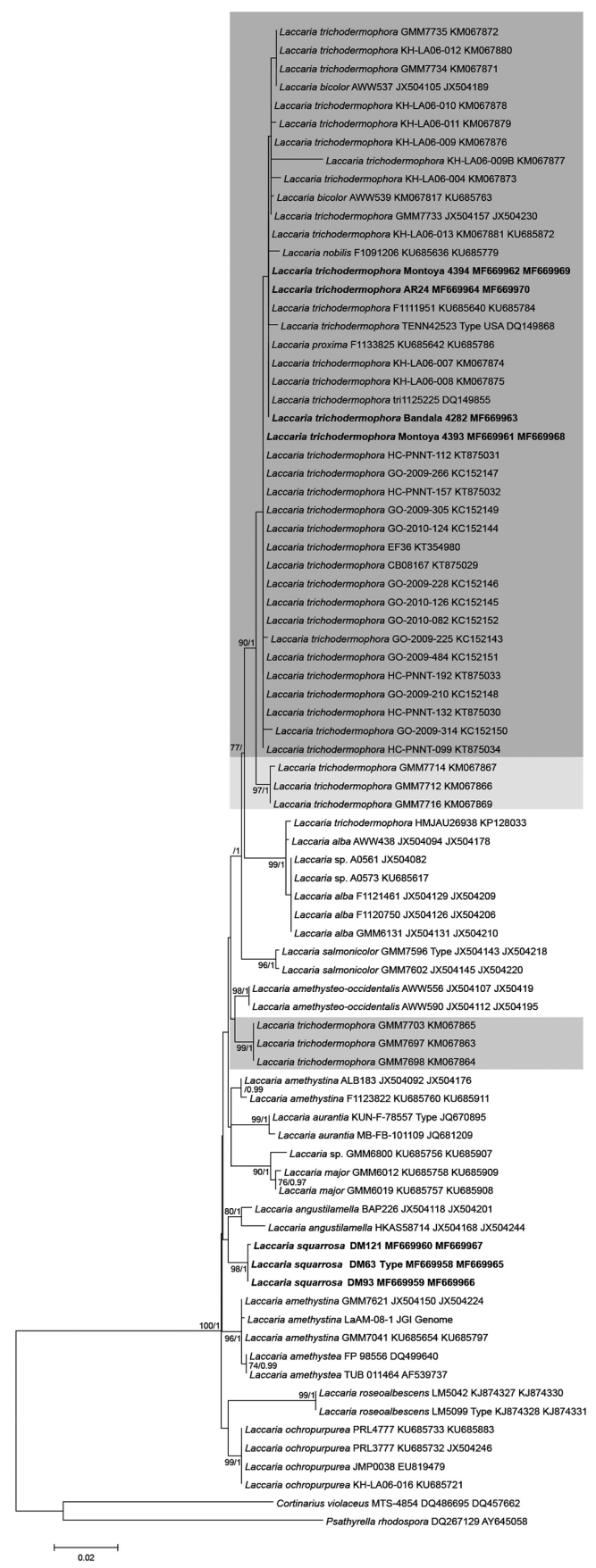

Figure I. Phylogenetic relationships within Laccaria species inferred from the combined ITS and LSU sequence data by maximum likelihood method. Tree with the highest $\log$ likelihood $(-4163.7219)$, the percentage of trees in which the associated taxa clustered together (only values $\geq 70 \%$ are considered) is shown next to the branches, followed by the posterior probabilities (only values $\geq 0.90$ are indicated) obtained after Bayesian inference. The tree is drawn to scale, with branch lengths measured in the number of substitutions per site. 


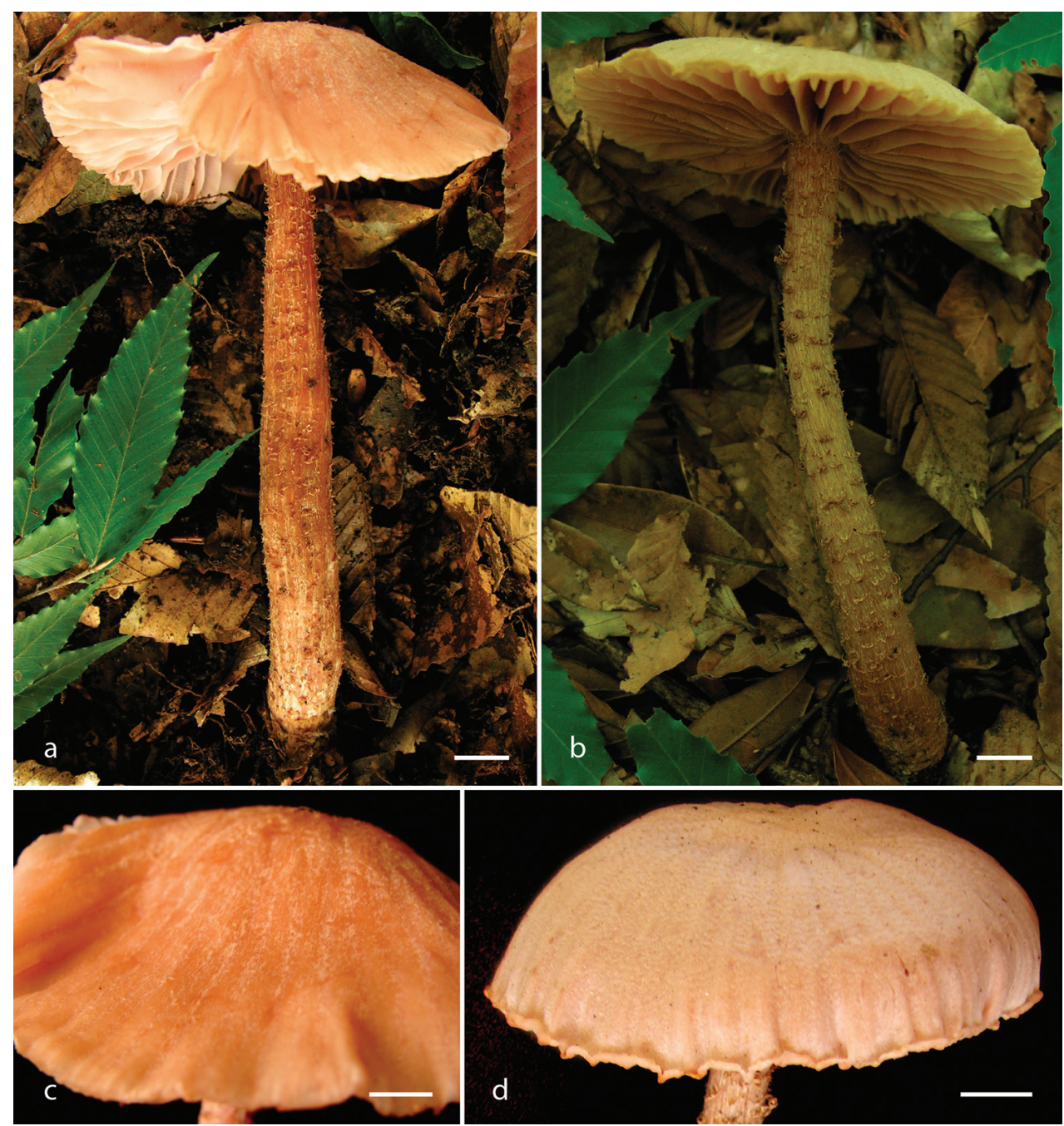

Figure 2. Laccaria squarrosa, basidiomes. a, b habit c, d pileus surface details a, c DM 121 b DM 63 (holotype) d DM 93. Scale bars: $10 \mathrm{~mm}$.

Diagnosis. Differs from other species by having medium sized basidiomes, with pinkish to pale brownish-orange colors, smooth to finely squarrose surfaces, especially on the stipe, basal mycelium with whitish to pale brownish with pinkish tinges, and globose, echinulate basidiospores, 7-10 $(-11.5) \times 7-10.5 \mu \mathrm{m}$, with the echinulae $0.5-1.4$ in length, $0.45-0.9 \mu \mathrm{m}$ in width at base, subcylindrical to contorted cystidia and pileipellis arranged in a cutis with mounds of intermixed and irregularly projected hyphae.

Gene sequences ex-holotype. MF669958 (ITS), MF669965 (LSU).

Etymology. referring to the characteristic squarrose surfaces of basidiomata.

Pileus 10-82 mm diam convex to plane-convex, at times slightly depressed at center, surface squamulose to squarrose with age, pinkish (6B3-2) with pale yellowish tinges 

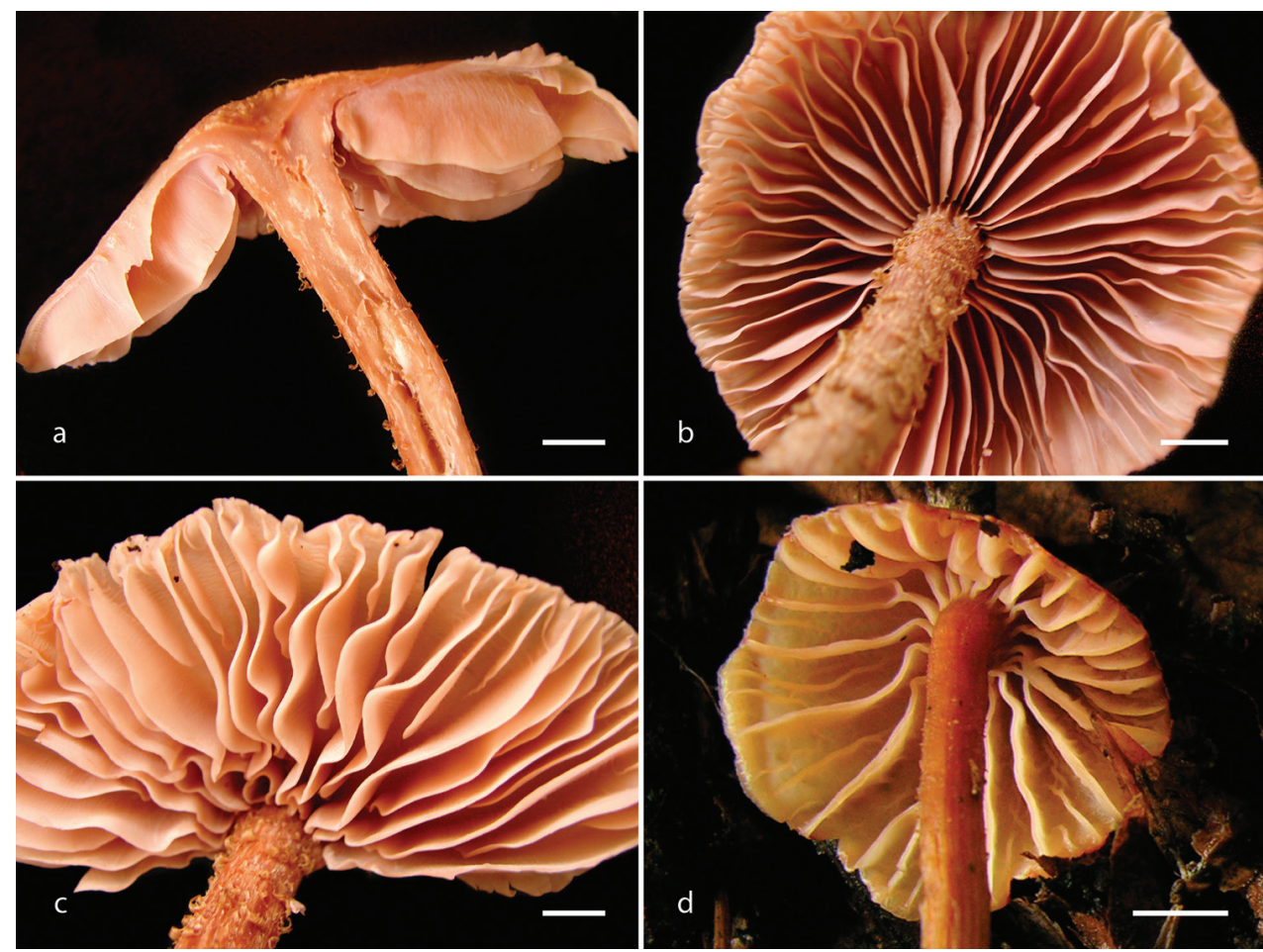

Figure 3. Laccaria squarrosa, lamellae attachment and habit. a, c DM 121 b DM 63 (holotype) d DM 93. Scale bars: $10 \mathrm{~mm}$.

towards the center or brownish-orange (5B6-5) when young; margin recurved, striate, edge thin. Lamellae 1-8 $\mathrm{mm}$ in length, adnate to subdecurrent, at times slightly undulate, subdistant or distant, pinkish to pale pinkish (6B4), 1-2 lamellulae per lamellae of different sizes. Stipe 50-155 × 5-9 mm, cylindrical, widened towards the base, squamulose to squarrose overall, more densely scaly towards the apex and when old, squamules brown, pinkish to ochraceous or ochraceous-orange. Basal mycelium pale whitish to brownish (6D6), with pinkish tinges in some areas. $\mathrm{KOH}$ negative overall surfaces.

Basidiospores 7-10 (-11.5) × 7-10.5 $\mu \mathrm{m}, \bar{X}=7.8-10.7 \times 7.7-9.48 \mu \mathrm{m}, \bar{Q}=1.01-$ 1.12 , globose, pale brownish, thin walled, hyaline, inamyloid, echinulate; under SEM the echinulae appear acute, 0.5-1.4 in length, 0.45-0.9 $\mu \mathrm{m}$ in width at base, shorter towards the hylar appendix area, this latter structure (also called the apiculus) consisting of a tube with rounded ending. Basidia 35-66 × 10-15 $\mu \mathrm{m}$, clavate to narrowly clavate, thin walled, mostly tetrasporic, at times tri- or bisporic, sterigmata $10 \mu \mathrm{m}$ length, some with refringent contents, clamped, hyaline. Pleurocystidia 20-38 $\times 3-6 \mu \mathrm{m}$, subcylindrical, contorted, sinuous, hyaline, thin walled. Cheilocystidia 14-40 × 2-5 $\mu \mathrm{m}$, subcylindrical, rarely narrowly utriform, contorted, sinuous, hyaline, thin walled. Pileipellis a regular compact cutis, hyphae periclinally oriented, also with projected mounds of intermixed hyphae, which form the pileus scales irregularly projected; hyphae cylindrical, some widened 4-10 $\mu \mathrm{m}$ diam, some septate, hyaline, inamyloid, yellowish in 


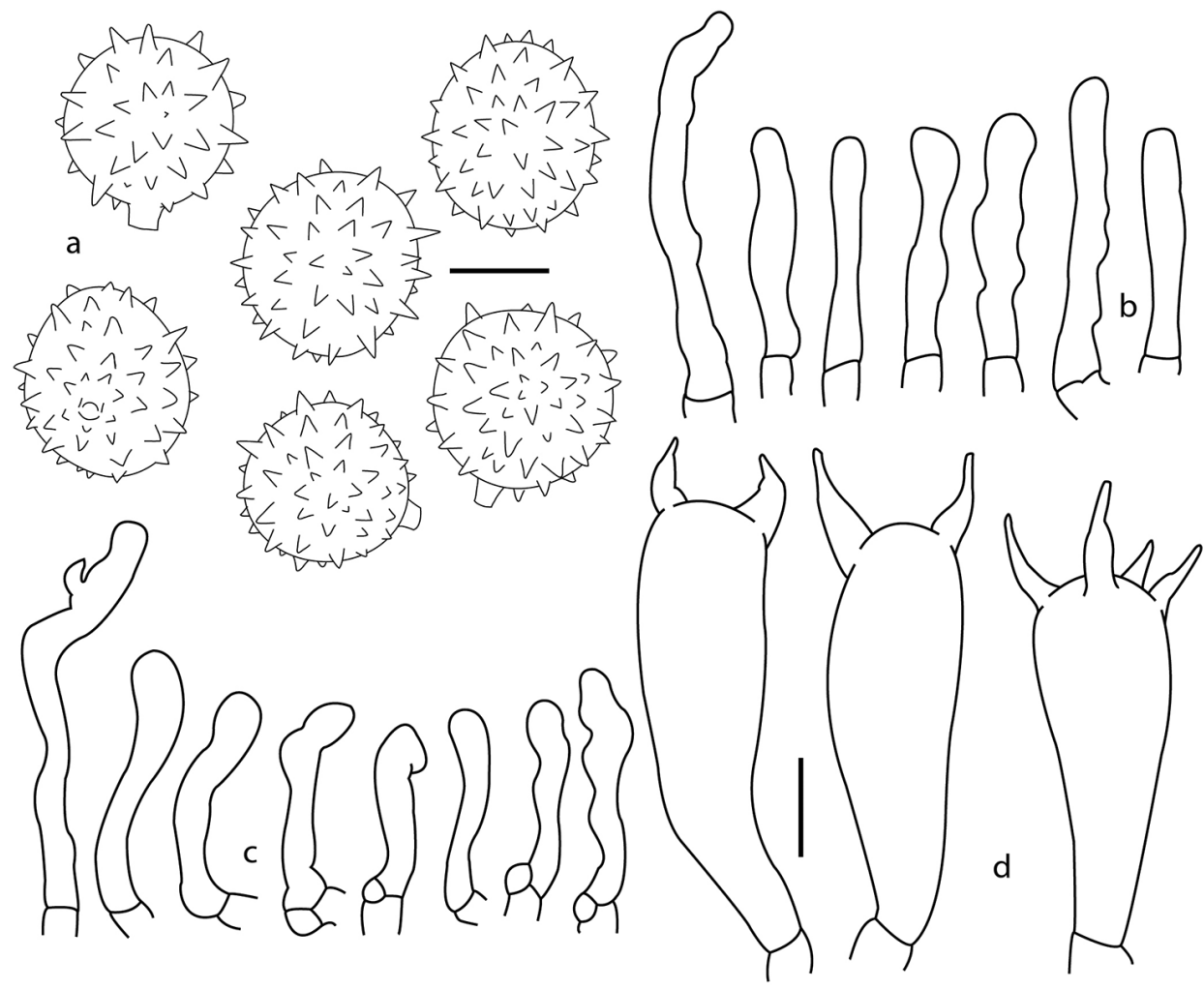

Figure 4. Laccaria squarrosa, a basidiospores b pleurocystidia c cheilocystidia $\mathbf{d}$ basidia a, c DM 121 b DM 63 (holotype) d DM 93. Scale bars: $5 \mu \mathrm{m}$ (a); $10 \mu \mathrm{m}$ (b-d).

mass and somewhat refringent in some parts, thin walled, clamped. Context hyphae cylindrical, faintly yellowish in mass, 4-9 (-14) $\mu \mathrm{m}$ diam, thin walled, up to $1 \mu \mathrm{m}$ diam, hyaline, inamiloyd, septate. Hymenophoral trama regular, compact, composed by cylindrical hyphae, pale yellowish in mass, $3-8 \mu \mathrm{m}$ diam, septate, hyaline and inamyloid, thin walled. Clamps present.

Habitat. Terrestrial, solitary, under Fagus grandifolia var. mexicana.

Additional studied material. MEXICO, Veracruz, Mpio. Acatlán, Volcán de Acatlán, Sep 18 2007, DM 121. Mpio. Acajete, Mesa de la Yerba, Aug 28 2007, DM 93 (all at XAL).

\section{Discussion}

In the phylogeny presented here that is based on sequences used in the worldwide survey of Laccaria by Wilson et al. (2017) and complemented with some from GenBank (Fig. 1) and sequences of $L$. squarrosa, described here, this new taxon is clearly shown to be phylogenetically isolated from other Laccaria species. Laccaria squarrosa is dis- 

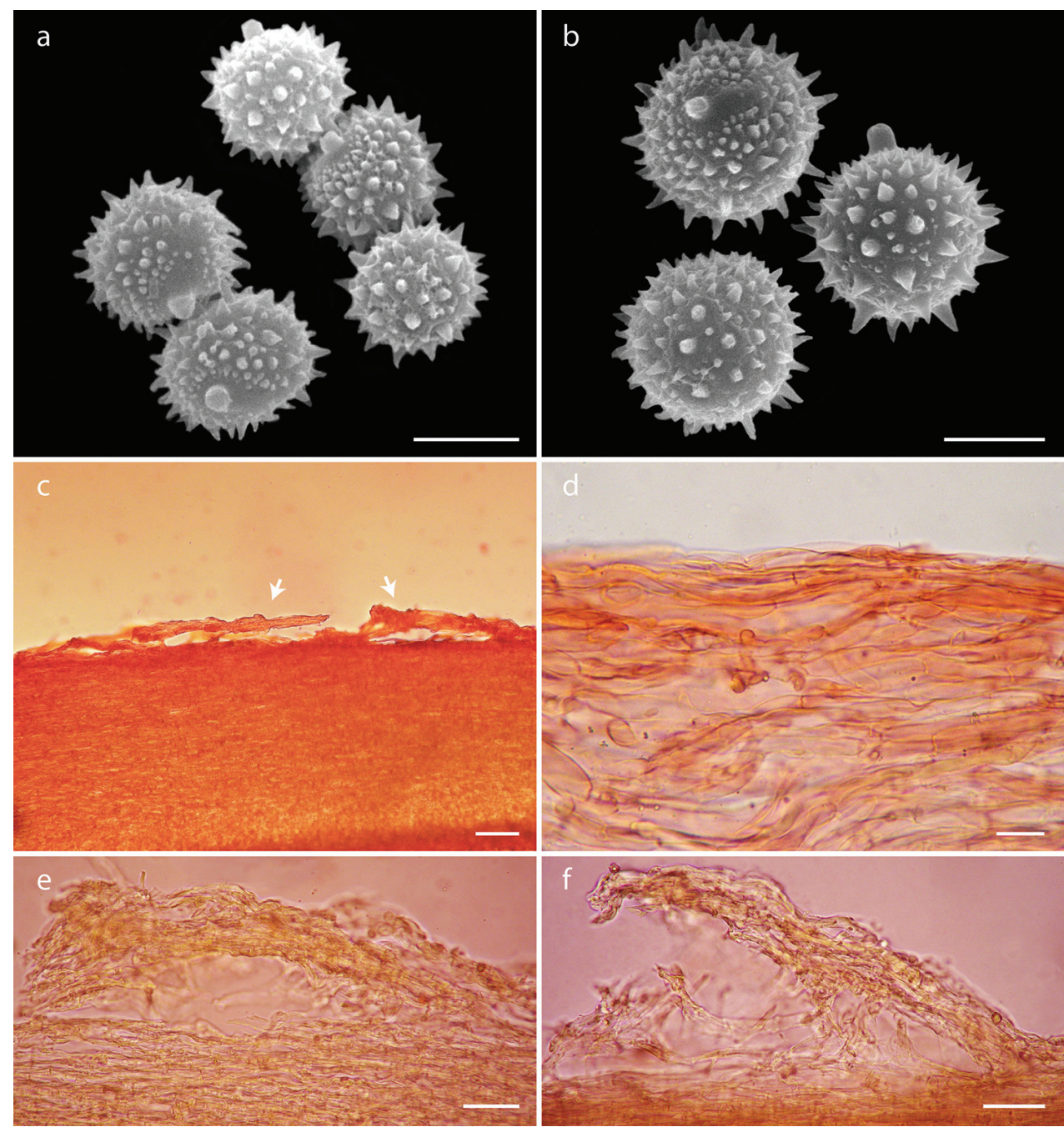

Figure 5. Laccaria squarrosa, $\mathbf{a}-\mathbf{b}$ basidiospores under SEM $\mathbf{c}-\mathbf{f}$ details of the pileipellis $\mathbf{c}-\mathbf{d}$ cutis (arrow indicating scales) e-f details of the pileipellis scales c-f DM 63 (holotype). Scale bars: $5 \mu \mathrm{m}(\mathbf{a}) ; 2 \mu \mathrm{m}$ (b); $100 \mu \mathrm{m}(\mathbf{c}) ; 20 \mu \mathrm{m}(\mathbf{d}) ; 50 \mu \mathrm{m}(\mathbf{e}-\mathbf{f})$.

tinct by possessing typical medium sized basidiomes with scaly surfaces, more obvious especially on the stipe and by having the basal stipe mycelium whitish to pale brownish with pinkish tinges. Microscopically it differs by globose, echinulate basidiospores, cylindrical cystidia and pileipellis arranged in a cutis with mounds of intermixed and irregularly projected hyphae. In Fig. 1, L. squarrosa is shown to be phylogenetically close to L. angustilamella Zhu L., Yang \& L. Wang from China. This later species is characterized, however, by having a marasmioid to mycenoid habit, with a short basidiome size (pileus 20-30 mm diam), narrow (2 mm length) and subdistant lamellae, 
non-scaly stipe, with more ellipsoid basidiospores ( $Q$ up to 1.18) and larger echinulae (2.0-) 2.5-5.0 $\mu \mathrm{m}$ long and up to $2.5 \mu \mathrm{m}$ wide at base (Wang et al. 2004).

Color features of the basidiomes and whitish mycelia relate Laccaria squarrosa to metasection Laccaria (Mueller 1992), where it superficially resembles L. proxima (Boudier) Patouillard. This later species, however, can be distinguished based on the longitudinally striate stipe, with a fibrillose surface only, ellipsoid basidiospores [9-11.5 × 6.7-8 (-8.8) $\mu \mathrm{m}, \mathrm{Q}=1.25-1.35(-1.4)]$, having shorter echinulae $(0.5-1$ $\mu \mathrm{m}$ length), pleurocystidia absence and larger cheilocystidia [19-66.5(-92) × 2-8.5(16.5) $\mu \mathrm{m}]$ (Mueller 1992). Among the species in the genus, Laccaria nobilis A.H. Smith, L. amethysteo-occidentalis G.M. Muell., L. trichodermophora and L. ochropurpurea (Berk.) Peck also produce fibrillose to somewhat scaly pileus surfaces. Laccaria ochropurpurea even can have recurved scales on the stipe surface. However, all those taxa clearly differ from Laccaria squarrosa by basidiomes and mycelia with violaceous colors, besides other macro and microscopical features (Mueller 1992).

Laccaria trichodermophora G.M. Mueller (Figs 6-7) was previously reported from Mexico (as L. farinacea sensu Singer) by Montoya et al. (1987) from conifer forests of Cofre de Perote National Park areas. The collections from Fagus grandifolia var. mexicana forest here studied, were collected in the locality of Mesa de la Yerba (Veracruz), on Aug 04 2005, Montoya 4393, Montoya 4394; Aug 28 2007, Bandala 4282 (XAL). Excepting by narrower hyphae disposed in the pileipellis mounds and the basidiospores including broadly ellipsoid to ellipsoid shapes, exhibit a similar morphological variation as those described by Mueller $(1984,1992)$ and other collections reported before from Mexico. A summary of the main morphological features that characterize the studied materials are: pileus $15-55 \mathrm{~mm}$ diam, fibrillose to fibrilloseminutely scaly, brownish-orange (6C6-C7), light brown or pale pinkish-brown or pale brownish towards the margin (6D6, 7C5-C4), hygrophanous. Lamellae 2-6 $\mathrm{mm}$ in length, adnate to sinuate, close to subdistant, pinkish or incarnate (6A2-B3). Stipe 20$75 \times 2-8 \mathrm{~mm}$, cylindrical, attenuated towards the apex, striate, fibrillose and fistulous. hygrophanous, concolorous to pileus but more pinkish-violaceous (13CD2) towards the base. Basal mycelium violaceous becoming white. Basidiospores 6-9 (-10) $\times 6-8.5$ $(-10) \mu \mathrm{m}, \bar{X}=6.9-8.18 \times 6.84-7.9 \mu \mathrm{m}, \bar{Q}=1.00-1.05$, globose, hyaline, echinulate, under SEM the echinulae appear 0.8-1.13 × 0.6-0.8 $\mu \mathrm{m}$. Basidia 27-65 (-80) $\times 7-13$ $\mu \mathrm{m}$, clavate, tetra or at times tri-sporic, hyaline, thin walled, clamped. Cheilocystidia $12-49 \times 2-6 \mu \mathrm{m}$ cylindrical to narrowly clavate, at times somewhat utriform, hyaline, thin walled, frequently clamped. Pileipellis composed of periclinally oriented hypahe 3-10 $\mu \mathrm{m}$ diam, in a more or less cutis arrangement but with frequent mounds of intermixed or erect hyphae, with terminal elements $25-125 \times 10-13 \mu \mathrm{m}$, cylindrical to clavate other somewhat utriform 20-65 × 5-17 $\mu \mathrm{m}$. Clamps present.

In the phylogeny obtained (Fig. 1), the sampled sequences of this species appear in three clades. One of them, with collections from North America, included the type specimen (DQ149868) and 21 specimens from Mexico. Our collections clustered in this later lineage interestingly with one sample from Costa Rica too. The other two clades are composed of specimens from Texas, one of them sister to the type clade, and 

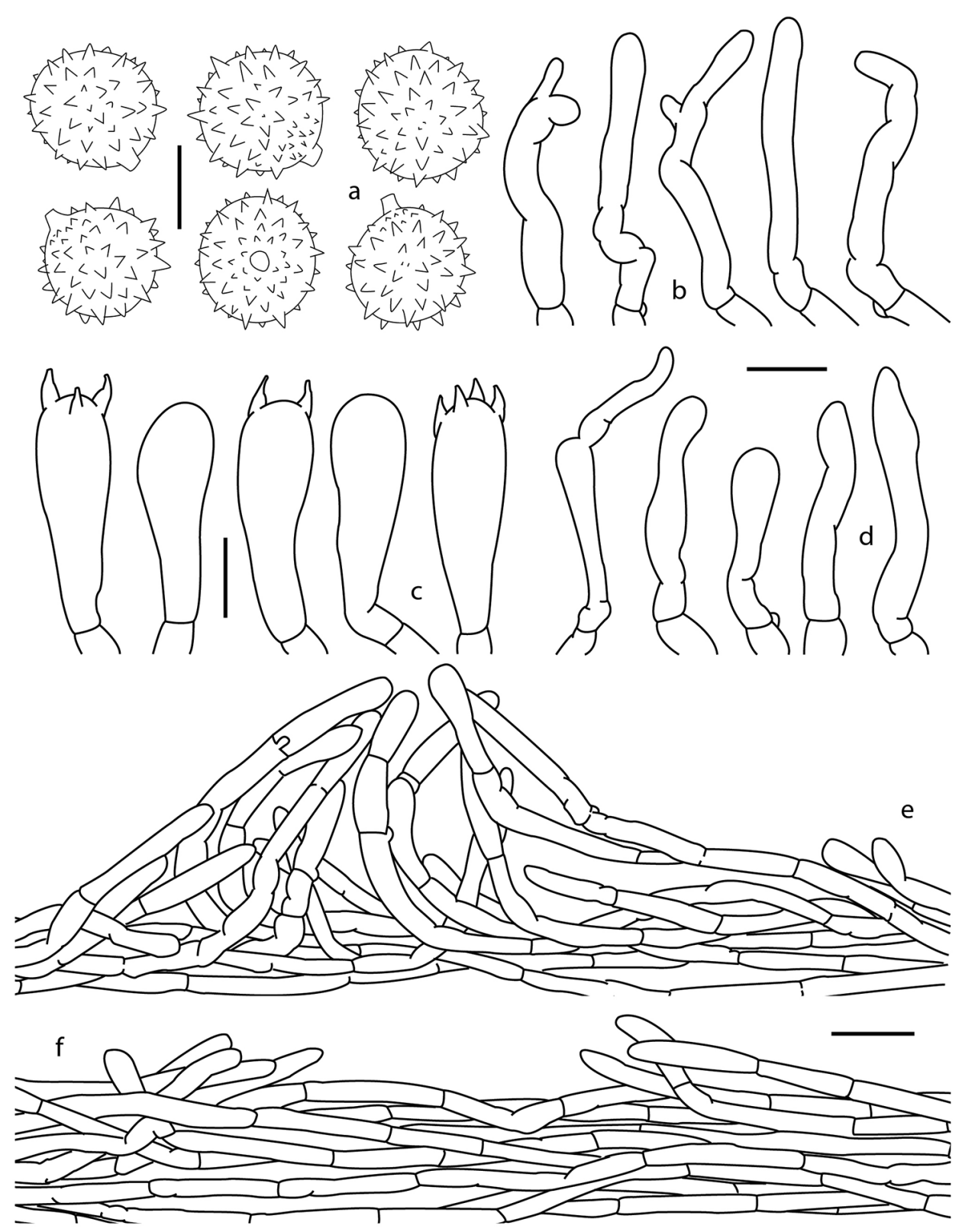

Figure 6. Laccaria trichodermophora, a basidiospores $\mathbf{b}$ pleurocystidia $\mathbf{c}$ basidia $\mathbf{d}$ pileipellis $\mathbf{e}$ cheilocystidia a-e Montoya 4393. Scale bars: $5 \mu \mathrm{m}(\mathbf{a}) ; 10 \mu \mathrm{m}(\mathbf{b}-\mathbf{c}, \mathbf{e}) ; 25 \mu \mathrm{m}(\mathbf{d})$.

the third clearly separated, probably representing an undescribed species. A specimen (KP128033) labeled as L. trichodermophora in the GenBank, clustered in L. alba group from Asia in our analysis. This sample lacks geographic information and could well be a misidentified collection. 

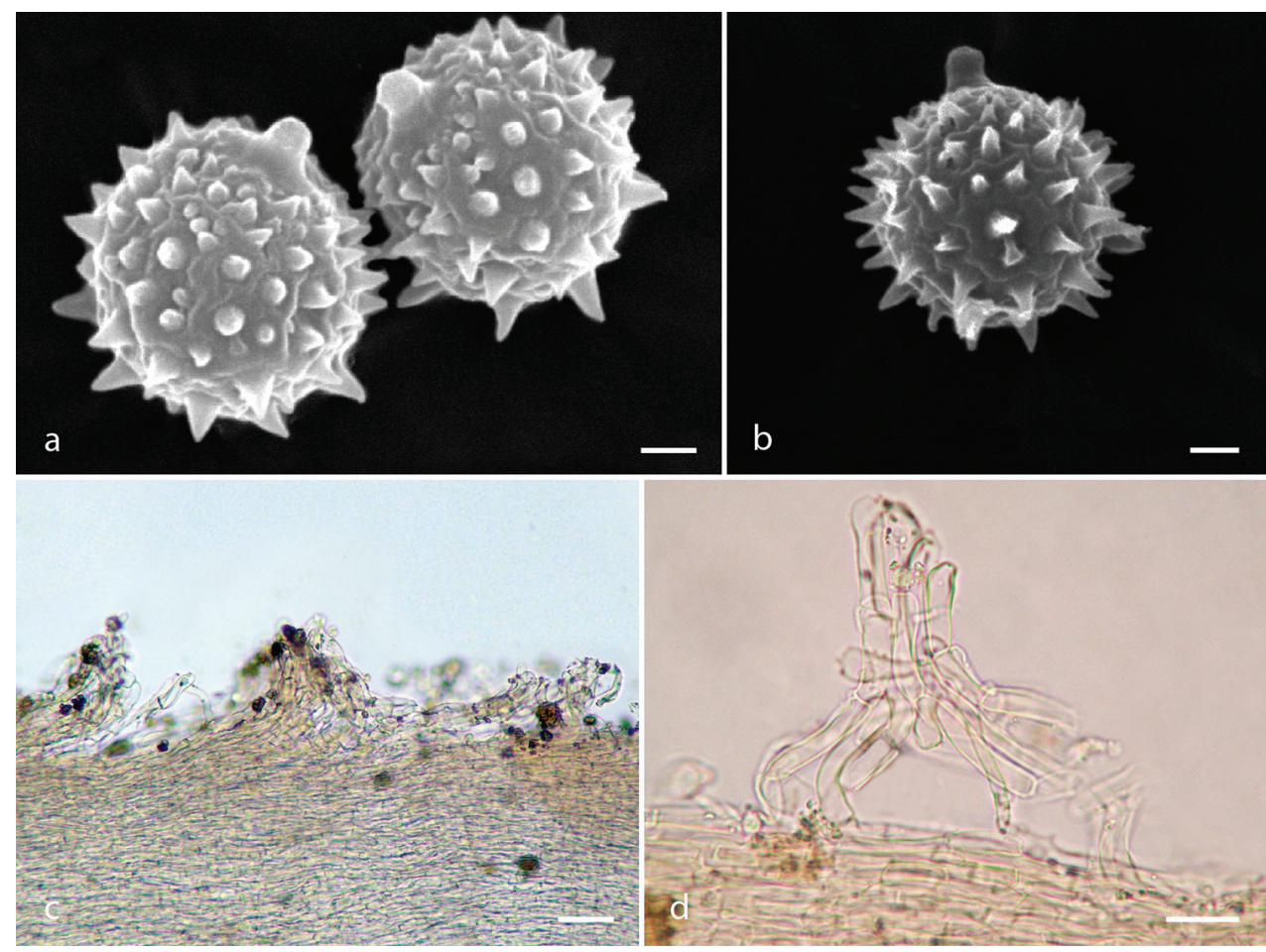

Figure 7. Laccaria trichodermophora, $\mathbf{a}-\mathbf{b}$ basidiospores under SEM c-d pileipellis a, c-d Montoya 4393 b Bandala 4282. Scale bars: $1 \mu \mathrm{m}(\mathbf{a}-\mathbf{b}) ; 50 \mu \mathrm{m}(\mathbf{c}) ; 25 \mu \mathrm{m}(\mathbf{d})$.

There are no previous reports of Laccaria trichodermophora being associated with Fagus grandifolia var. mexicana. This report serves as the first documentation of this association. According to the reports of L. trichodermophora, it shows a wide ecological range. Mueller (1992) observed that all collections of this Laccaria species from the southeastern United States appeared to be associated with Pinus. He also collected it, in Costa Rica, beneath Neotropical species of Quercus. In central Mexico, in the states of Tlaxcala and Michoacán, it has been recorded associated to mixed Pinus-Alnus and Pinus-Abies forests (Montoya et al. 1987, Montoya-Esquivel et al. 2004). In the eastern part of Mexico, in Veracruz, it has been found (as L. farinacea sensu Singer) in monodominant Pinus and mixed Pinus-Abies forests (Montoya et al. 1987). In this later country, it is interesting to note that, basidiomes of this species, specially from conifers, are sold in local markets as edible fungi (Montoya et al. 1987, MontoyaEsquivel et al. 2004). Based on the available ecological information of the samples in the phylogenetic tree (Fig. 1), a wide host range for L. trichodermophora type specimen clade can be inferred. Among the potential hosts, it can be recognized as occurring with Fagus grandifolia, Pinus elliottii, P. palustris and Quercus sp. in Texas, as well as P. patula, other species of Pinaceae and Quercus spp. in both US and in Mexico, and the endangered F. grandifolia var. mexicana as confirmed here. Abies religiosa represents 
another host also, as proved by data from two sequences (MF669964 and MF669970) (Table 1, Fig. 1) obtained here, from the sample AR24, from an A. religiosa forest at Cofre de Perote National Park in Veracruz, Mexico.

\section{Acknowledgments}

We appreciate the assistance in the field and in the laboratory by Biol. D. Ramos (at Instituto de Ecología, A.C.), Biól. J.C. Corona and Ing. Alicia García. We recognize the support given by CONACYT (CB 169172) to study the EcM fungi associated with Fagus grandifolia var. mexicana in the montane cloud forest of Central Veracruz and by the postdoctoral grant to A. Ramos. We acknowledge the support given by CONACYT (225382) to the Laboratorio de Presecuenciación, Red Biodiversidad y Sistemática, INECOL. M.Sc. Bertha Pérez at this lab aid in some molecular procedures.

\section{References}

Aguirre-Acosta E, Pérez-Silva E (1978) Descripción de algunas especies del género Laccaria (Agaricales) de México. Boletín de la Sociedad Mexicana Micología 12: 33-58.

Bandala VM, Guzmán G, Montoya L (1988) Especies de macromicetos citadas de México VII. Agaricales, parte II (1972-1987). Revista Mexicana de Micología 4: 205-250.

Bandala VM, Montoya L (2000) A taxonomic revision of some American Crepidotus. Mycologia 92: 341-353. https://doi.org/10.2307/3761571

Benson DA, Cavanaugh M, Clark K, Karsch-Mizrachi I, Lipman DJ, Ostell J, Sayers EW (2017) GenBank. Nucleic Acids Research 45: D37-D42. https://doi.org/10.1093/nar/gkw1070

Carrasco-Hernández V, Pérez-Moreno J, Espinosa-Hernández V, Almaraz-Suárez JJ, QuinteroLizaola R, Torres-Aquino M (2010) Caracterización de micorrizas establecidas entre dos hongos comestibles silvestres y pinos nativos de México. Revista Mexicana de Ciencias Agrícolas 1: 567-577.

Cifuentes J, Villegas M, Pérez-Ramírez L, Bulnes M, Corona V, González MR, Jiménez I, Pompa A, Vargas G (1990) Observaciones sobre la distribución, habitat e importancia de los hongos en Los Azufres, Michoacán. Revista Mexicana de Micología 6: 133-149.

Galindo-Flores G, Castillo-Guevara C, Campos-López A, Lara C (2015) Caracterización de las ectomicorrizas formadas por Laccaria trichodermophora y Suillus tomentosus en Pinus montezumae. Botanical Sciences 93(4): 855-863. https://doi.org/10.17129/botsci.200

Gardes M, Bruns D (1993) ITS primers with enhanced specifity for basidiomycetes application to the identification of mycorrhizae and rusts. Molecular Ecology 2: 113-118. http://dx.doi. org/10.1111/j.1365-294x.1993.tb00005.x

Garibay-Orijel R, Martínez Ramos M, Cifuentes J (2009) Disponibilidad de esporomas de hongos comestibles en los bosques de Pino-Encino de Ixtlán de Juárez, Oaxaca. Revista Mexicana de Biodiversidad 80: 521-534. 
Irving F, Crossley A, Mason PA, Last FT, Wilson J, Natarajan K (1985) Characteristics of some species of Laccaria, a fungal genus of significance to forestry, temperate and tropical. Proceedings Indian Academy of Sciences: Plant Sciences 95: 321-331. https://doi.org/10.1007/BF03053243

Jargeat P, Martos F, Carriconde F, Gryta H, Moreau PA, Gardes M (2010) Phylogenetic species delimitation in ectomycorrhizal fungi and implications for barcoding: the case of the Tricholoma scalpturatum complex (Basidiomycota). Molecular Ecology 19: 5216-5230. https://doi.org/10.1111/j.1365-294X.2010.04863.x

Kornerup A, Wanscher JH (1967) Methuen Handbook of Colour (2nd edn). Methuen, London. Kropp BR, Mueller GM (1999) Laccaria. In: Cairney JWG, Chambers SM (Eds) Ectomycorrhizal Fungi Key Genera in Profile. Springer, Berlin, Heidelberg, 65-88. https://doi.org/10.1007/9783-662-06827-4_3

Lampman AM (2007) General principles of Ethnomycological classification among the Tzeltal Maya of Chiapas, Mexico. Journal of Ethnobiology 27: 11-27. https://doi.org/10.2993/02780771(2007)27[11:GPOECA]2.0.CO;2

Luo X, Ye L, Chen J, Karunarathna SC, Xu J, Hyde KD, Mortimer PE (2016) Laccaria rubroalba sp.nov. (Hydnangiaceae, Agaricales) from Southwestern China. Phytotaxa 284(1): 41-50. http://dx.doi.org/10.11646/phytotaxa.284.1.4

McNabb RFR (1972) The Tricholomataceae of New Zealand 1. Laccaria Berk. \& Br. New Zealand Journal of Botany 10: 461-484. https://doi.org/10.1080/0028825X.1972.10428618

Montoya L, Bandala VM (2003) Studies on Lactarius a new combination and two new species from Mexico. Mycotaxon 85: 393-407.

Montoya L, Bandala VM, Baroni T, Horton TR (2015) A new species of Laccaria in a montane cloud forest from Eastern Mexico. Mycoscience 56(6): 597-605. https://doi.org/10.1016/j. myc.2015.06.002

Montoya L, Bandala VM, Garay E (2014) Two new species of Lactarius associated with Alnus acuminata subsp. arguta in Mexico. Mycologia 106: 949-962. http://dx.doi. org/10.3852/14-006

Montoya L, Bandala VM, Guzmán G (1987) Nuevos registros de hongos del Estado de Veracruz, IV Agaricales II (con nuevas colectas de Coahuila, Michoacán, Morelos y Tlaxcala). Revista Mexicana de Micología 3: 83-107.

Montoya L, Bandala VM, Ramos A, Garay-Serrano E (2017) The ectomycorrhizae of Lactarius rimosellus and Lactarius acatlanensis with the endangered Fagus grandifolia var. mexicana. Symbiosis 1-10. http://dx.doi.org/10.1007/s13199-017-0489-0

Montoya-Esquivel A, Estrada-Torres A, Caballero J (2002) Comparative ethnomycological survey of three localities from La Malinche volcano, México. Journal of Ethnobiology 22: 103-132.

Montoya-Esquivel A, Hernández-Totomoch O, Estrada-Torres A, Kong A, Caballero J (2003) Traditional knowledge about mushrooms in a Nahua community in the state of Tlaxcala, México. Mycologia 95: 793-806. http://dx.doi.org/10.1080/15572536.2004.11833038

Montoya-Esquivel A, Kong A, Estrada-Torres A, Cifuentes J, Caballero J (2004) Useful wild fungi of La Malinche National Park, México. Fungal Diversity 17: 115-143.

Mueller GM (1984) New North American species of Laccaria (Agaricales). Mycotaxon 20: 1010-116. 
Mueller GM (1992) Systematics of Laccaria (Agaricales) in the continental United States and Canada, with discussions on extralimital taxa and descriptions of extant types. Fieldiana Botany 30: 1-158. https://doi.org/10.5962/bhl.title.2598

Mueller GM, Sundberg W (1981) A floristic study of Laccaria (Agaricales) in Southern Illinois. Nova Hedwigia 34: 577-597.

Müller J, Müller K, Neinhuis C, Quandt D (2010) PhyDE ${ }^{\oplus}$ - Phylogenetic Data Editor, version 0.9971. Program distributed by the authors. http: Ilwww.phyde.de

Osmundson TW, Cripps CL, Mueller GM (2005) Morphological and molecular systematics of Rocky Mountain alpine Laccaria. Mycologia 97(7): 949-972. http://dx.doi.org/10.1080/ 15572536.2006.11832746

Pérez-Moreno J, Martínez-Reyes M, Yescas-Pérez A, Delgado-Alvarado A, Xoconostle-Cázares B (2008) Wild Mushroom Markets in Central Mexico and a Case Study at Ozumba. Economic Botany 62(3): 425-436. https://doi.org/10.1007/s12231-008-9043-6

Pérez-Silva E, Esqueda M, Herrera T, Coronado M (2006) Nuevos registros de Agaricales de Sonora, México. Revista Mexicana de Biodiversidad 77: 23-33.

Popa F, Jimenéz SYC, Weisenborn J, Donges K, Rexer KH, Piepenbring M (2016) A new Laccaria species from cloud forest of Fortuna, Panama. Mycological Progress 15: 1-8. http://dx.doi. org/10.1007/s11557-015-1139-7

Popa F, Rexer KH, Donges K, Yang ZL, Kost G (2014) Three new Laccaria species from Southwest China (Yunnan). Mycological Progress 13: 1105-1117. http://dx.doi.org/10.1007/ s11557-014-0998-7

Rambaut A (2016) FigTree v1.4.3 software. Institute of Evolutionary Biology, University of Edinburgh. Available at: http://tree.bio.ed.ac.uk/software/figtree/

Rodríguez-Ramírez EC, Sánchez-González A, Ángeles-Pérez G (2013) Current distribution and coverage of Mexican beech forests Fagus grandifolia subsp. mexicana in Mexico. Endangered Species Research 20(3): 205-216. https://doi.org/10.3354/esr00498

Ronquist F, Teslenko M, van der Mark P, Ayres DL, Darling A, Höhna S, Larget B, Liu L, Suchard MA, Huelsenbeck JP (2012) MrBayes 3.2: efficient Bayesian phylogenetic inference and model choice across a large model space. Systematic Biology 61: 539-542. http:// dx.doi.org/10.1093/sysbio/sys029

Roy M, Dubois MP, Proffit M, Vincenot L, Desmarais E, Selosse MA (2008) Evidence from population genetics that the ectomycorrhizal basidiomycete Laccaria amethystina is an actual multihost symbiont. Molecular Ecology 17: 2825-2838. https://doi.org/10.1111/ j.1365-294X.2008.03790.x

Santiago-Martínez G, Estrada-Torres A, Varela L, Herrera T (2003) Crecimiento en siete medios nutritivos y síntesis in vitro de una cepa de Laccaria bicolor. Agrociencia 37: $575-584$

Sheedy E, Van de Wouw AP, Howlett BJ, May TW (2013) Multigene sequence data reveal morphologically cryptic phylogenetic species within the genus Laccaria in southern Australia. Mycologia 105: 547-563. http://dx.doi.org/10.3852/12-266

Singer R (1967) Notes sur le genre Laccaria. Bulletin trimestriel de la Société Mycologique de France 83: 104-123. 
Tamura K, Stecher G, Peterson D, Filipski A, Kumar S (2013) MEGA6: molecular evolutionary genetics analysis version 6. Molecular Biology and Evolution 30: 2725-2729. http://dx.doi. org/10.1093/molbev/mst197

Taylor JW, Turner E, Townsend JP, Dettman JR, Jacobson D (2006) Eukaryotic microbes, species recognition and the geographic limits of species: examples from the kingdom Fungi. Philosophical Transactions of the Royal Society of London B: Biological Sciences 361: 1947-1963. https://doi.org/10.1098/rstb.2006.1923

Vilgalys R, Hester M (1990) Rapid genetic identification and mapping of enzymatically amplified ribosomal DNA from several Cryptococcus species. Journal of Bacteriology 172: 4238-4246. https://doi.org/10.1128/jb.172.8.4238-4246.1990

Vincenot L, Nara K, Sthultz C, Labbé J, Dubois MP, Tedersoo L, Martin F, Selosse MA (2012) Extensive gene flow over Europe and possible speciation over Eurasia in the ectomycorrhizal basidiomycete Laccaria amethystina complex. Molecular Ecology 21: 281-299. https://doi.org/10.1111/j.1365-294X.2011.05392.x

Wang L, Yang ZL, Liu JH (2004) Two new species of Laccaria (Basidiomycetes) from China. Nova Hedwigia 79: 511-517. http://dx.doi.org/10.1127/0029-5035/2004/0079-0511

White TJ, Bruns T, Lee S, Taylor JW (1990) Amplification and direct sequencing of fungal ribosomal RNA genes for phylogenetics. In: Innis MA, Gelfand DH, Sninsky JJ, White TJ (Eds) PCR protocols: a guide to methods and applications. Academic Press, San Diego, 315-322. http://dx.doi.org/10.1016/B978-0-12-372180-8.50042-1

Wilson AW, Hosaka K, Mueller GM (2017) Evolution of ectomycorrhizas as a driver of diversification and biogeographic patterns in the model mycorrhizal mushroom genus Laccaria. New Phytologist 213: 1862-1873. https://doi.org/10.1111/nph.14270

Wilson AW, Hosaka K, Perry BA, Mueller GM (2013) Laccaria (Agaricomycetes, Basidiomycota) from Tibet (Xizang Autonomous Region, China). Mycoscience 54(6): 406-419. http://dx.doi.org/10.1016/j.myc.2013.01.006 